\title{
2 THE WILL OF THOMAS JUXON ${ }^{65}$
}

In the name of God amen, I Thomas Juxon, second son of Mr John Juxon late of East Sheen in the parish of Mortlake in the county of Surrey, being through the goodness of God in good health and memory, do make this may last will and testament as followeth. And first I do humbly lay hold upon the tender of salvation by Jesus Christ, who is the only saviour of mankind, that through His infinite goodness $\mathrm{He}$ will be pleased to pardon, cleanse and sanctify me throughout and present me unto God the Father at the great day of judgement clothed with His righteousness and discharged from all my debts by the satisfaction which He made in my nature unto the divine justice in His voluntary death upon the cross. And I do commit my immortal soul into the protection of the holy, blessed and undivided Trinity, Father, Son and Holy Ghost, three persons and one God, to be admitted into that state of glory which is the purchase of the holy Jesus, even the glorious liberty of the sons of God; a state totally freed from sin and from temptations and from all desires or inclinations to $\sin -\mathrm{a}$ state of purity, of eternal and uninterrupted love, delight and praises of, in and to the undivided Trinity.

Secondly, I do dispose of my temporal estate in manner following. I do given and bequeath my mansion house in East Sheen aforesaid, with all the land thereunto belonging inclosed with a pale, unto my nephew Thomas Juxon during the life of my dear son William Juxon with the issues and profits, that he may be therewith enabled to maintain my said son with necessaries. And after the death of my dear son I give the said mansion house and lands unto his heirs for ever; I say unto the heirs of my son William Juxon for ever and not otherwise.

Item, whereas by a deed of feoffment dated the sixth of October 1670 made at Dublin between me Thomas Juxon, Standish Hartstrong and John Petty deceased, and my son William Juxon of the other part, I, the said Thomas Juxon, for the natural affection I bear unto my son did settle all my castles, houses and lands, with all and every of their appurtenances, situated, lying and being in the county of Limerick, unto him and to his heirs, paying thereout yearly the sum of one hundred pounds clear of all charges unto my dear daughter Elizabeth Juxon so long as she shall live unmarried, and also with liberty to me, the said Thomas Juxon, to alter the uses therein limited or to add other

${ }_{658}^{8}$ PRO, PROB II $/ 34^{\circ / 147}$ 
uses as in and by the said deed by me signed and left with the said John Petty doth and may more fully appear; in pursuance whereof I, the said Thomas Juxon, do hereby further after limit, direct, appoint. And I give unto my dear daughter Elizabeth Juxon for the natural affection I bear unto her all my said castles, houses and lands, with all and every their appurtenances, situated in the said county of Limerick and kingdom of Ireland and to her heirs for ever; to the intent that the said lands may be sold and that two thirds thereof may be to my dear son William Juxon when he shall be cured of his melancholy distemper (according to an agreement made by me with Mr Newton, where now he lodges) and not before, and to the heirs of my said son; and that he may be, in the meantime, maintained by my said daughter as she shall think good and not otherwise; and for want of heirs by my said son lawfully begotten then the moiety of the proceed of the said lands to my nephews Thomas Juxon and George Juxon of London, sons of my brother John Juxon deceased.

Item, whereas by a lease bearing date the seventh of October 1670 between me Thomas Juxon of the one part, and Sir Charles Meredith, knight, and Samuel Mollineux of the City of Dublin, esquire, of the other part, I did let and set unto the said Sir Charles Meredith and Samuel Mollineux for two years certain lands in the county of Meath and Queen's county in Ireland, and by a release bearing date the eighth of the said month and year I did release unto the said Sir Charles Meredith and Samuel Mollineux all my right etc. in and to the said lands in trust; nevertheless, and for the uses therein named, and for such other uses as I, the said Thomas Juxon, should by my last will and testament etc. declare as by the said release in the hands of Sir Charles Meredith may appear, in pursuance whereof $I$, the said Thomas Juxon, do hereby further limit, direct and appoint that in case I have no son by my dear wife then I give unto my dear daughter Elizabeth Juxon the lands of Dirpatrick set unto Robert Lutterrell, and the lands of the Grange set unto Thomas Hessam, for and during her natural life, and after her death to my said nephew Thomas Juxon and to his heirs; and in case I have no child by my dear wife then I do give unto my said dear daughter Elizabeth Juxon and to her heirs all the rest of the lands mentioned in the said lease and release. And I do further give unto my said daughter all the overplus of the rents and profits arising out of the lands before mentioned after the payment of three hundred pounds a year payable to my dear wife during her natural life, and after the payment of six pounds, six shilling, eight pence unto my dear sister Byfield for the term of twenty years, if she shall so long live; and after her death, during the remainder of the twenty years, the same to be paid to my nephew Tristram Davis and to his assigns; and also paying unto him, the said Tristram Davis, and 
to his assigns during the term of twenty years to come, yearly thirteen pounds, six shilling, four pence; which two sums make up £20 per annum - the rent of the land that my said nephew, in right of his wife, is to receive, that was sold to Colonel Thomas Coote and of which my said nephew released to him all his right, title and interest; which release is with Mr John Ramsay of Dublin in the exchequer. Out of the said $£_{20}$ per annum my sister Sara Byfield hath a third part paid to her as before is said.

Item, my meaning, my mind and will is that the forementioned lands of Dirpatrick and of the Grange, after the death of my daughter Elizabeth Juxon, shall be to the heirs of my son William Juxon lawfully to be gotten before they come to my nephew Thomas Juxon; and for want of such heirs then to my said nephew Thomas Juxon and not otherwise; and that during the life of my said son they, my daughter and my nephew, shall maintain out of the said lands my said son as they shall think good and not otherwise; and for the rest of the lands shall be sold and the one moiety thereof be to the heirs of my son William Juxon lawfully begotten; and for default thereof the one half of the said moiety I give to the children of my dear sister Sara Byfield and the other moiety to the children of my cousins Matthew Sheppard, Nicholas Juxon and John Juxon.

Item, I give unto my dear daughter Elizabeth Juxon my leases and interest in the house and nursery in Mortlake with all the goods therein and thereunto belonging.

Item, I do give unto my dear wife one third part of what shall be recovered upon the statute staple of one thousand pounds from Colonel Thomas Coote unto me, and one third of what shall be recovered from his heirs etc. upon the non-performance of covenants made from him to me; and I do give unto my dear wife all my plate and goods in Dublin and going thither.

Item, I do give unto my nephew Timothy Byfield and to his heirs my farm of Barberies, with the appurtenances, lying in Danesbury in the county of Essex, and the sum of sixty pounds to repair the same and twelve pounds to pay the fine to the lord and other charges.

Item, I give unto my dear sister the rent of the lands which I bought of the Briggeses lying in the barony of Deece and county of Meath, being per annum cleared of all charges $£^{21}$ i6s. for and during her life; and I give unto the sons of my said sister, Timothy and Nathaniel, and to their heirs the said lands with like appurtenances.

Item, I give unto my niece Elizabeth Davis the sum of fifty pounds, to my niece Rebecca Jackson fifty pounds, to my niece Sara Byfield one hundred pounds out of the two thirds of the forementioned statute.

Item, I give the sum of twenty pounds to be laid out in erecting a monument in the remembrance of Maurice Carent, esquire, and the 
Lady Elizabeth his wife, the father and mother of my dear wife deceased, in the church of Henstridge by Woodyates in the county of Dorset; provided that the lands of Toomer etc. do descend to my children and their heirs, my brother James Carent dying without children, according to the settlement made of the said estate with other land by the said Maurice Carent, esquire, and not otherwise.

Item, I will that there be erected in the church of Islington a marble in the wall near where my dear wife lies buried with this inscription: 'Here lies buried the body of Elizabeth Juxon late the wife of Thomas Juxon, esquire, daughter of Maurice Carent of Toomer Park in the county of Somerset, esquire, and the Lady Elizabeth his wife, the eldest daughter of James, earl of Marlborough, lord treasurer of England etc. ${ }^{69}$ which said Elizabeth Juxon died the [blank] of September I669 leaving two children, William and Elizabeth', over the said marble supported with flat columns my coat impaled with Carent and Toomer quarterly, the first argent, 3 hurtes charged with 3 chevernelles gules, the second argent, 3 bars wavy, gules and my crest upon a helmet etc. above the escutcheon.

Item, I give the sum of twelve pounds to be laid out in repairing the almshouses at East Sheen and for setting up a stone with father's coat and crest cut and coloured.

Item, I give to Christopher Cane, to Goodman Lee, to George Dally and to Goody Beavie fifty shillings to each of them; to Mr Brinsley's brother-in-law that lives in Old Brentford, to Dr Rolls ${ }^{660}$ and to $\mathrm{Mr}$ Thomas, parsons of Dublin, and to my cousin William Juxon late of Virginia to each of them ten pounds.

Item, I give to my dear cousin Sir William Juxon, knight and baronet, to my cousin James Carent, esquire, to my good friend Standish Hartstrong, esquire, to my cousin Matthew Sheppard, to my cousin John Juxon, to the eldest son of my cousin John Kirrell deceased, to my sister Byfield, to my nephews Thomas and George Juxon, to all the children of my sister Byfield, to my brother Sir Charles Meredith, to my brother Robert Meredith, ${ }^{661}$ to my sister Lister, and to my sister the countess of Mountrath, ${ }^{662}$ to each of them twenty ounces of plate. To my dear Lady Anne Coote the spleen-stone after the death of my

\footnotetext{
${ }^{69}$ Sir James Ley, first Lord Ley I624, first earl of Marlborough I626, lord treasurer I624-28; died 14 March I629.

${ }^{660}$ Dr Daniel Rolls, chaplain to Colonel Sadler's regiment in 1654 , minister at Swords in 1654 and at St Bride's Dublin in ${ }^{6} 657$ : St John Seymour, The puritans in Ireland (Oxford, I9I2), pp. II5, 220.

${ }^{601}$ Sir Charles and Robert Meredith were Juxon's brother-in-laws through his second wife, Elizabeth, daughter of Sir Robert Meredith of Greenhills, county Kildare.

${ }_{662}$ Charles Coote, the second earl of Mountrath, was married to Alice, the daughter of Sir Robert Meredith (above), Thomas Juxon's sister-in-law through his second marriage.
} 
dear sister the countess of Mountrath; to my niece Farrington and my niece Kenricke, to my nephew John Key, to each of them twenty ounces of plate, and to Mr John Ramsay of the exchequer in Dublin twenty ounces of plate.

Item, I give to Patrick Corr's wife forty shillings to buy her three silver spoons, and to John Osborne forty shilling, and to my apprentice with him five pounds when he comes out of his time.

Item, I give unto the three youngest daughters of my sister Byfield that are unmarried one hundred pounds, viz. to the eldest forty, and the two youngest, thirty pounds apiece.

Item, I do give unto my nephews Thomas Juxon and George Juxon my interest in Pincocke Lane in London, with the benefit of a decree lately given by the judges in that case.

And lastly I do publish and declare this to be my last will and testament written all with my own hand containing six whole sides besides this, and I do hereby revoke and declare null and void all other and former wills, in particular my will left with Mr John Ramsay in Dublin, and I do declare my dear daughter Elizabeth Juxon the executrix of this my last will and testament, unto whom I give all the rest of my estate both personal and real not herebefore given, and my nephew Thomas Juxon the overseer, and I do give him twenty pounds a year for his care and pains which he shall take in assisting my said executrix in the management of her trust. Given under my hand and seal and dated this 6th day of June 1672, Thomas Juxon sealed and delivered in the presence of us William Doley, William Threlfall, William Witter Examinatus.

Probatum fuit testamentum suprascriptum apud London coram venerabili et egregio viro domino Leolino Jenkins milite legum doctore curiae prerogativae Cantuarensis magistro custode sive commissario legitime constituto vicesimo primo die mensis Decembris anno domini millesimo sexcentesimo septuagesimo secundo juramento Elizabethae Juxon filiae dicti defuncti et executricis unicae in huiusmodi testamento nominatae cui accommissa fuit administraco omnium et singulorum bonorum jurium et creditorum eiusdem defuncti de bene et fideliter administrando eadem ad sancta Dei evangelia [juratae]. ${ }^{663}$

$<$ [margin] Concordat cum originale testamento facta collacione per nos Thomas Juxon, Richard Edes. 30 December $1672 .{ }^{66}$

\footnotetext{
${ }^{663}$ The above-written will was proved in London before that worshipful and honourable man, Sir Leoline Jenkins, knight, doctor of civil law, master, warden or legally appointed commissary of the prerogtive court of Canterbury, on the 2ist day of December A.D. I672, upon the oath of Elizabeth Juxon, daughter of the said deceased person, after she swore an oath on God's holy gospels well and faithfully to administer the same.

${ }^{664}$ Agrees with the original will a comparison having been made by us Thomas Juxon, Richard Edes. 30 December 1672.
} 
Received the original will of the said deceased to return according to the tenor of a bond entered into by me Elizabeth Juxon, teste Richard Edes> 